\title{
Spektrometryczne pomiary gamma rdzeni wiertniczych o niskiej aktywności
}

\section{Spectrometric gamma measurements of low radioactivity cores}

\author{
Rafał Skupio ${ }^{1}$, Krzysztof Wolański² \\ ${ }^{1}$ Instytut Nafty i Gazu - Państwowy Instytut Badawczy \\ ${ }^{2}$ Polskie Górnictwo Naftowe i Gazownictwo S.A.
}

\begin{abstract}
STRESZCZENIE: W pracy przedstawiono nową metodykę pomiarową spektrometrii gamma dla rdzeni wiertniczych reprezentowanych przez skały o niskiej aktywności. Opisano w niej części składowe nowo zaprojektowanego spektrometru wraz z dedykowanym oprogramowaniem testowym. Badania prowadzone według zaproponowanej procedury stosowane są głównie do rdzeni formacji piaskowcowych czerwonego spągowca, dla których dotychczas w Polsce nie wykonywano pomiarów gamma. Pierwsze testy na rdzeniach piaskowcowych prowadzono z wykorzystaniem standardowego spektrometru - gamma logger BGO (GL), przy wydłużonym czasie pomiarowym, co pozwoliło uzyskać zaledwie częściowe wyniki dla wybranego odcinka rdzenia. Opracowanie nowego urządzenia wykorzystującego dwa niezależnie mierzące detektory BGO, umieszczone pod kątem 90 stopni w ołowianym tunelu (aparatura GLGT) umożliwiło dwukrotne skrócenie czasu pomiarowego, poprawienie dokładności wyników oraz obniżenie poziomu detekcji dla analizowanych pierwiastków (potas, uran oraz tor). Wstępne badania porównawcze w otworze testowym ukazały różnice pomiędzy aparatem GL i GLGT. Polegały one na poprawie jakości rejestrowanych danych w szczególności dla uranu i toru, które w przypadku standardowych analiz przyjmowały wartości mniejsze od tła pomiarowego. Dodatkowe badania przeprowadzono na wzorcach kalibracyjnych w postaci walca o znanej koncentracji pierwiastków promieniotwórczych, których wyniki posłużyły głównie do oceny rozdzielczości obu metod. Seria pomiarów rdzeni z otworu J-1 pozwoliła otrzymać dokładne wyniki porównawcze z aparatów GL i GLGT, które przedstawiono na tle profilowań geofizyki otworowej oraz badań laboratoryjnych. W przypadku tego testu wyniki z aparatury GLGT wykazały się poprawą dokładności, lepszym dopasowaniem do profilowań oraz poprawą rozdzielczości pionowej w stosunku do geofizyki wiertniczej. Uzyskane wyniki pomiarów spektrometrem GLGT wykorzystano do określenia tła pomiarowego, szacunkowej rozdzielczości oraz określenia dokładnych zawartości potasu, uranu i toru w otworach archiwalnych. Wyniki końcowe przedstawiono w postaci krzywych spektrometrycznego profilowania gamma.
\end{abstract}

Słowa kluczowe: promieniowanie gamma, pomiary rdzeni, radiometria, spektrometria.

ABSTRACT: This paper shows a new methodology of gamma spectrometry measurements dedicated to cores represented by rocks of low radioactivity. It describes the components of the newely developed spectrometer and the dedicated testing software. The measurements conducted according to the proposed procedure are mostly applied for Rotliegend formation cores, for which spectral gamma core logging has never been done before in Poland. The first tests on the sandstone cores were conducted using a standard spectrometer - gamma logger BGO (GL) with an extended measurement time, which allowed obtain partial results for chosen core interval. The construction of the new device, which uses two independent BGO detectors placed at a 90-degree angle in lead tunnel shielding (GLGT apparatus), made it possible to twice shorten the measurement time, improve the accuracy of the results, and reduce the detection limit for the analysed elements (potassium, uranium, thorium). Preliminary comparative studies performed on the core from the test borehole showed differences between gamma logger GL and the GLGT device. These differences were visible especially for uranium and thorium data, which in the case of standard (GL) surveys carried values that were lower than the measurement background. Additional measurements were carried out on calibration standards in the form of a cylinder with a known concentration of radioactive elements, the results of which were used for evaluating the core logging resolution of both methods. The series of core measurements from J-1 borehole allowed to obtain accurate comparative results from GL and GLGT devices, which were presented against well logging and laboratory analyses. In the case of this test, the results from GLGT apparatus showed an improvement in measurement accuracy, better fitting to the well logs, and a higher vertical resolution in relation to spectral gamma logs. The results of the measurements performed with a GLGT spectrometer were used to define the measurement background, the estimated resolution, as well as to define the accurate content of potassium, uranium and thorium in the archival boreholes. All the final results were presented as curves of spectral gamma logs.

Key words: gamma radiation, core measurements, radiometry, spectrometry.

Autor do korespondencji: R. Skupio, e-mail: rafal.skupio@inig.pl

Artykuł nadesłano do Redakcji 11.01.2019 r. Zatwierdzono do druku 14.05.2019 r. 


\section{Wstęp}

Ciągłe pomiary naturalnej promieniotwórczości gamma na rdzeniach wiertniczych do tej pory wykonywane były w Polsce dla skał łupkowych o wysokiej koncentracji potasu K-40, uranu U-238 i toru Th-232 (Skupio i Dohnalik, 2015). Pomiary na rdzeniach skał o niskiej aktywności (utwory karbonu, czerwonego spągowca) nie są możliwe do wykonania przy zastosowaniu standardowo używanej metody. Powodem jest tło pomiarowe, które jest duże w przypadku urządzeń z cienkim ekranem. Jego aktywność może być wyższa niż aktywność samego rdzenia (szczególnie w przypadku uranu i toru). Na sygnał tła składa się promieniowanie pochodzące m.in. z: podłoża, materiałów budowlanych, promieniowania kosmicznego, lokalnie występującego radonu, obudowy detektora oraz samego kryształu (Carconi et al., 2012; Amanat et al., 2013; Korun et al., 2014; Baldoncini et al., 2017; Lindstorm, 2017; Melintescu et al., 2018). W pracy, w celu obniżenia wpływu tła zastosowano aparaturę z osłoną o grubości $10 \mathrm{~cm}$. Materiał do budowy ekranu w postaci ołowianych pierścieni pochodził z wycofanego z eksploatacji urządzenia typu MAZAR. Dla skrócenia czasu pomiarowego, wykorzystano dwa jednocześnie rejestrujące detektory scyntylacyjne BGO.

Wyniki pomiarów gamma na rdzeniach wykorzystywane są głównie w celu dopasowania głębokości miary wiertniczej (rdzeń) do geofizycznej (profilowania), poprawy rozdzielczości pionowej oraz do oceny wpływu płuczki na poszczególne zawartości pierwiastków promieniotwórczych. Umożliwiają również szacowanie takich parametrów, jak: zailenie, zawartość substancji organicznej, określenie środowiska depozycyjnego, rozpoznanie procesów diagenetycznych w skałach osadowych oraz przybliżonej litologii (Skupio, 2017). Ponadto w przypadku reinterpretacji archiwalnych otworów wiertniczych pozwalają na uzupełnienie zestawu profilowań o wyniki spektrometryczne oraz umożliwiają wykalibrowanie krzywej całkowitego promieniowania gamma zapisanej w jednostkach imp/min na jednostki API (Bolesta i Gałązka, 2014; Galford, 2017). Pomiary gamma podczas wiercenia otworu (LWD) wykorzystywane są również do korekcji jego trajektorii (Chao et al., 2015).

\section{Aparatura badawcza}

Urządzenia wykorzystywane do pomiarów radiometrycznych $w$ geologii dają informacje na temat całkowitej promieniotwórczości gamma materiałów wraz z podziałem na: potas $\left({ }^{40} \mathrm{~K}\right)$, uran $\left({ }^{238} \mathrm{U}\right)$ oraz tor $\left({ }^{232} \mathrm{Th}\right)$. Metody analizy widmowej w przypadku trójkanałowej metody interpretacji oparte są na intensywności pików charakterystycznych dla energii potasu $-1,46 \mathrm{MeV}$, uranu $-1,76 \mathrm{MeV}$ i toru $-2,62 \mathrm{MeV}$
(Blum et al., 1997). Aparatura jest kalibrowana przy pomocy wzorców w postaci walca o znanej zawartości każdego z wymienionych pierwiastków. W badaniach brały udział dwa aparaty wykorzystywane do pomiarów całych rdzeni wiertniczych zbudowane na bazie dwucalowych detektorów BGO - gamma logger $\mathrm{BGO}$ (GL) oraz gamma logger 2xBGO (GLGT). Materiał $\mathrm{BGO}\left(\mathrm{Bi}_{4} \mathrm{Ge}_{3} \mathrm{O}_{12}\right.$ - germanian bizmutu) cechuje się zwiększoną gęstością, w stosunku do najczęściej stosowanego kryształu NaI(Tl), co wpływa na polepszenie jego wydajności (Graaf et al., 2007; saintgobain, 2015). Kryształ dzięki niewielkim rozmiarom pozwala na uzyskanie większej rozdzielczości pomiaru w stosunku do sondy otworowej. W pracy, do potwierdzenia dokładności otrzymanych profilowań wykorzystano wyniki pomiarów laboratoryjnych wykonanych metodą akredytowaną, spektrometrem typu MAZAR (Procedura PB-04/SW-1, 2018).

Standardowo stosowany przy pomiarach naturalnej promieniotwórczości gamma spektrometr Gamma Logger BGO - GL (Procedura PB-14/SW-1, 2012), jest dedykowany do pomiarów metrowych odcinków rdzeni i posiada zautomatyzowany system przesuwczy. Ustawienia spektrometru pozwalają dopasować czas pomiarowy od 30 do 600 sekund. Krok pomiarowy mieści się w zakresie od 2 do $50 \mathrm{~cm}$. Osłona rdzenia w punkcie pomiarowym ma grubość ścianki $5 \mathrm{~cm}$ oraz długość $40 \mathrm{~cm}$. Detektor ustawiony jest w centralnej części obudowy i przesuwany nad rdzeniem wraz z obudową. Wymienione parametry dobrze sprawdzają się przy badaniach skał łupkowych, dla których stosowano krótki czas pomiarowy ustawiony na 1 minutę. Dla większości piaskowców wydłużenie czasu pomiarowego do 10 minut pozwala uzyskać zadowalające wyniki. Niestety aparat nie pozwala na pełną rejestrację krzywych profilowania spektrometrycznego w przypadku utworów piaskowcowych o niskiej aktywności. Głównym powodem jest zbyt wysokie tło pomiarowe oraz zbyt krótki czas akwizycji ograniczony przez aparaturę.

Wykonanie pomiarów rdzeni o niskiej promieniotwórczości naturalnej wymagało zaprojektowania nowej aparatury (rys. 1). Prace nad układem detekcyjnym zostały zaplanowane w taki sposób, aby osiągnąć cel badawczy z maksymalnym wykorzystaniem własnych środków. Do budowy osłony wykorzystano ołów z uszkodzonej aparatury MAZAR, która idealnie pasowała do niniejszego spektrometru z powodu jej kształtu oraz wieku materiału, który z pewnością cechuje się niższą radioaktywnością od świeżych stopów. Bloki ołowiu zostały tak połączone, aby umożliwić wykonywanie pomiarów na rdzeniach o średnicy 6-7 cm lub 10-11 cm. Grubość osłony w przypadku pomiarów rdzeni o średnicy do $7 \mathrm{~cm}$ wynosi $10 \mathrm{~cm} \mathrm{w}$ punkcie pomiarowym i sięga do około $20 \mathrm{~cm}$ od detektora. Możliwość odłączenia od siebie poszczególnych segmentów pozwala na ich łatwy transport. Pomiary mogą zostać wykonane bezpośrednio w magazynie bez konieczności wypożyczania rdzeni wiertniczych i narażania ich na uszkodzenia podczas transportu. 
Ma to szczególne znacznie w przypadku rdzeni archiwalnych, których stan fizyczny jest słaby. W celu łatwego wprowadzania rdzenia do komory pomiarowej zbudowano podajniki rolkowe na wejściu i wyjściu z tunelu. Zastosowanie dwóch detektorów ustawionych w stosunku do siebie pod kątem 90 stopni pozwala dwukrotnie skrócić czas analiz. Detektory podłączone są do komputera przez port USB, który również pełni funkcję zasilania. Układ detekcyjny wraz z oprogramowaniem został stworzony przez firmę Georadis s.r.o., która specjalizuje się zarówno w radiometrycznych badaniach laboratoryjnych, jak i produkcji urządzeń do pomiarów pierwiastków promieniotwórczych. Kompletny spektrometr został stworzony przy ścisłej współpracy z Zakładem Geofizyki Wiertniczej INiG - PIB. Oprogramowanie do obsługi zestawu detektorów pozwala na jednoczesny pomiar dwóch widm spektrometrycznych i zapis do folderu zbiorczego.

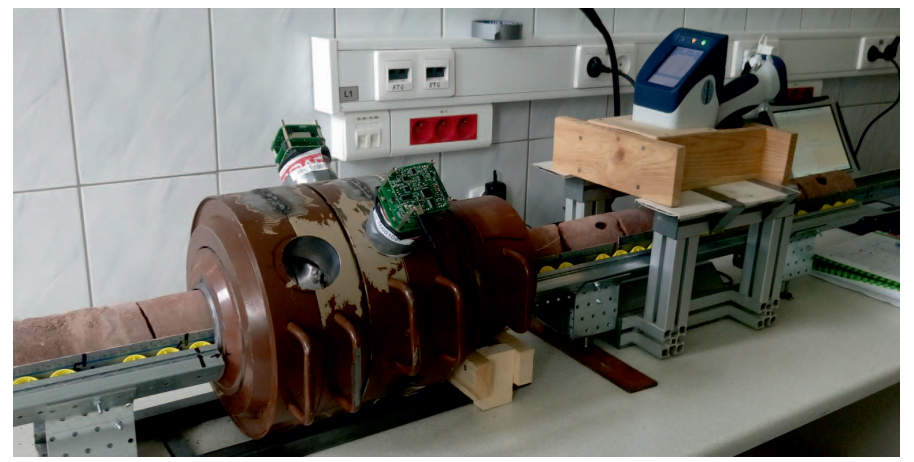

Rys. 1. Spektrometr Gamma Logger 2xBGO (GLGT) do pomiarów naturalnej promieniotwórczości rdzeni wiertniczych o niskiej aktywności

Fig. 1. Gamma Logger spectrometer 2xBGO (GLGT) dedicated to low radioactivity core measurements

\section{Wyniki badań}

Pomiary prowadzone były na wzorcach kalibracyjnych, całych rdzeniach wiertniczych oraz pokruszonych próbkach pobranych z rdzeni. Pomiary na rdzeniu wiertniczym najlepiej jest wykonać zaraz po wydobyciu go z otworu, przed pobraniem prób na badania laboratoryjne. Pozwala to na osiągnięcie najlepszych wyników z całości dostępnego materiału oraz może być pomocne przy typowaniu prób do dalszych dokładniejszych analiz. Badania naturalnej promieniotwórczości gamma należą do grupy metod nieinwazyjnych - materiał po wykonaniu pomiarów jest w stanie nienaruszonym. W przypadku kompletnego rdzenia ustalany jest stały krok pomiarowy - standardowo $10 \mathrm{~cm}$. Dla pomiarów rdzeni archiwalnych, z których wcześniej pobrano znaczne ilości materiału przeznaczonego na badania laboratoryjne, stosuje się zmienny krok pomiarowy lub usuwa zaniżone wyniki z pustych odcinków. Punkty pomiarowe w przypadku zmiennego kroku typuje się na podstawie dostępności materiału rdzeniowego i jego formy. Pozwala to zaoszczędzić czas i osiągnąć lepsze wyniki.

\section{Pomiary tła}

Spektrometr GLGT powstał z myślą o pomiarach rdzeni o niskiej aktywności, stąd najważniejszym czynnikiem wymagającym poprawy jest tło pomiarowe, które powinno być na jak najniższym poziomie (Fornasa i Sanches-Conde, 2015). W celu oceny zmniejszenia wpływu tła, wykonano pomiary porównawcze w urządzeniach GL i GLGT. Analizie poddano wzorzec aluminiowy (nieaktywny) oraz odcinek rdzenia piaskowcowego o niskiej aktywności. Pomiary spektrometrem GL i GLGT wykonane były przy czasie ustawionym na 10 min, aby zapewnić podobną ilość zliczeń i dokładność. Wyniki przeprowadzonych badań zestawiono na rysunku 2.
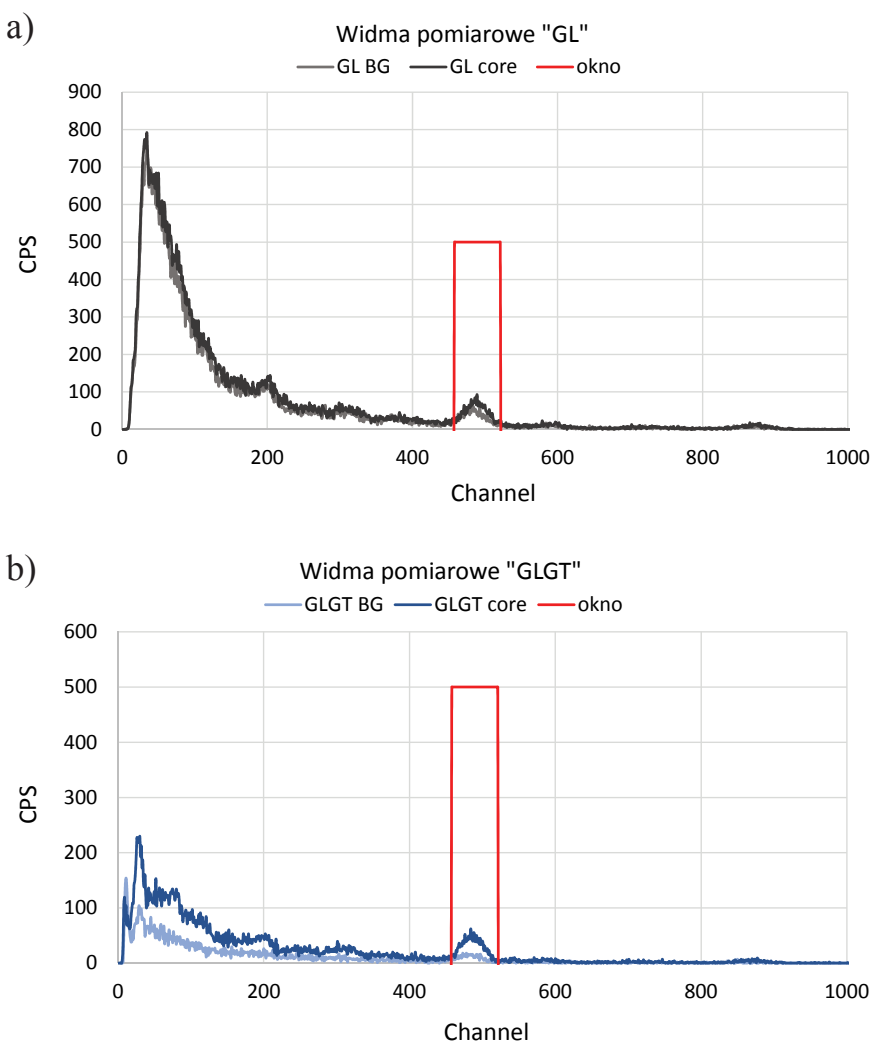

Rys. 2. Wyniki badań tła pomiarowego oraz odcinka rdzenia; a) widma $z$ GL, b) widma z GLGT

Fig. 2. Results from background and core measurements; a) GL spectra, b) GLGT spectra

Wyniki pomiarów wykazały poprawę (obniżenie) zarejestrowanych wartości tła w przypadku spektrometru GLGT. Wykresy ukazują znaczną różnicę w sygnale pochodzącym od rdzenia i od tła pomiarowego w przypadku aparatu GLGT. Dla piku potasowego o charakterystycznej energii 1,46 MeV (analizowany obszar zaznaczono na wykresach - „okno”), wykonano 
porównanie ilości zliczeń. Dla pomiarów spektrometrem GL różnica w ilości zliczeń pomiędzy tłem, a rdzeniem wynosiła 882 CPS. Obliczony błąd standardowy dla wartości tła w zaznaczonym obszarze wynosił 14 CPS. Wartości te gwarantują otrzymanie poprawnego wyniku dla potasu w przypadku pomiarów aparatem GL. W przypadku GLGT różnica pomiędzy tłem a rdzeniem wynosiła 1271 CPS. Odchylenie standardowe było natomiast równe $5 \mathrm{CPS}$. Oznacza to znaczną poprawę, zarówno w ilości zliczeń otrzymywanych z pomiaru, jak i większą dokładność zarejestrowanego widma.

\section{Ocena rozdzielczości pomiarowej na podstawie wzorców kalibracyjnych}

Pomiary laboratoryjne nie są obarczone wpływem warstw przyległych, gdyż odseparowana próbka jest umieszczona w komorze pomiarowej. Dokładna rozdzielczość pionowa metody pomiaru rdzeni jest trudna do oszacowania i wymagałaby zbudowania wielu modeli rdzeni o różnej grubości warstw. Szacunkowa rozdzielczość pomiarów aparatami GL i GLGT została oceniona na podstawie pomiaru czterech połączonych ze sobą wzorców o średnicy $7 \mathrm{~cm}$ i długości $30 \mathrm{~cm}$. Pomiary wykonano w czasie 1 minuty dla każdego punktu z krokiem pomiarowym wynoszącym $2 \mathrm{~cm}$. Wyniki pomiarów przedstawiono na rysunku 3 .

Wykres przedstawia wyniki pomiarów wzorca nieaktywnego (tło), torowego, potasowego oraz uranowego. Punkt pomiarowy 0 na osi $\mathrm{x}$, to miejsce w którym pod detektorem znajdował się wzorzec nieaktywny. Wzorzec torowy był natomiast w odległości $20 \mathrm{~cm}$ od detektora (na granicy osłony). Dla tego punktu nie zauważono wpływu wzorca. Pierwsze wskazania dla toru na poziomie $20 \mathrm{ppm}$ pojawiły się w odległości $12 \mathrm{~cm}$ (8 punkt pomiarowy) od detektora. Stały wzrost wartości następuje w odległości $6 \mathrm{~cm}$ od detektora. Referencyjne wartości wzorca torowego otrzymano na jego środkowej części, na 35 centymetrze. Podobne zjawisko odnotowano dla pomiarów

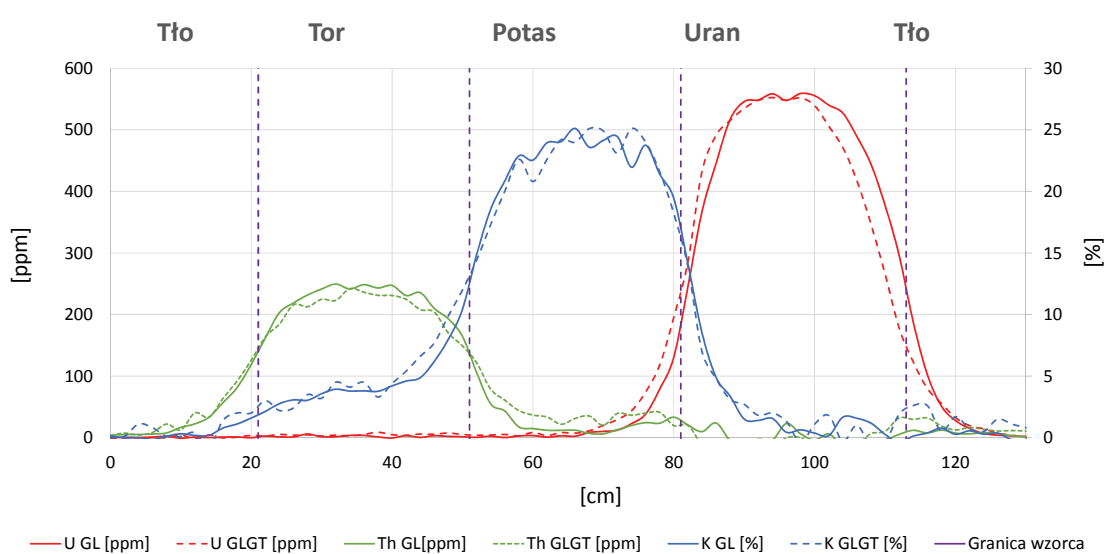

Rys. 3. Zestawienie wyników pomiarów wzorców spektrometrem GL i GLGT

Fig. 3. Data summary of standards measurements by GL and GLGT spectrometers pozostałych wzorców. Każdy z nich wykazywał się znacznym wzrostem wskazań w odległości około $10 \mathrm{~cm}$ od detektora. Wartości referencyjne otrzymywano natomiast w momencie ustawienia się detektora bezpośrednio nad jego środkową częścią. W przypadku pomiaru wzorca torowego odnotowano podwyższoną zawartość potasu w jego strukturze, co jest uwzględniane przy kalibracji spektrometru.

Spektrometr GLGT oraz GL zbudowane są na bazie dwucalowego detektora BGO. Różnica w budowie urządzeń polega głównie na innym układzie geometrycznym obudowy, która odgrywa znaczenie przy pomiarach rdzeni skał o niskiej promieniotwórczości oraz ilości detektorów. Zawężenie otworu, przez który wprowadzany jest rdzeń do detektora podczas pomiarów nie zwiększyło rozdzielczości metody. Porównanie wykazało, że za rozdzielczość metody odpowiada głównie wielkość kryształu detekcyjnego. Na podstawie przeprowadzonych badań można stwierdzić, że rozdzielczość obu urządzeń jest identyczna i wynosi około $20 \mathrm{~cm}$. Dla porównania sondy otworowe mają rozdzielczość pionową około $40 \mathrm{~cm}$ (Rider, 1996). Przeprowadzony test wykazał również wysoką powtarzalność metod i dokładność wyników pomiarów wzorców kalibracyjnych. Na podstawie testów można stwierdzić, że minimalny odcinek rdzenia umieszczany w komorze powinien wynosić około $30 \mathrm{~cm}$. Krótszy rdzeń będzie powodował zaniżenie wyniku.

\section{Pomiary rdzeni wiertniczych o niskiej aktywności}

Interwał rdzenia testowego reprezentujący piaskowce czerwonego spągowca został wybrany na podstawie wyników geofizycznych pomiarów otworowych (rys. 4) „Geofizyka”. W pierwszej kolejności wykonano badania rdzeni standardową aparaturą gamma logger - GL. Czas pomiarowy ustawiono na $10 \mathrm{~min}$, a krok na $10 \mathrm{~cm}$. W górnym interwale od głębokości $3520 \mathrm{~m}$ do głębokości $3523 \mathrm{~m}$, dla koncentracji uranu część wartości jest ujemna. Natomiast w odcinku od głębokości $3526 \mathrm{~m}$ do $3531 \mathrm{~m}$ wszystkie wartości dla koncentracji uranu są mniejsze od zera. $Z$ tych dwóch interwałów, wytypowano odcinki rdzeni do badań na nowej aparaturze GLGT, w tunelu ołowianym (krzywa przerywana). Pomiary GLGT wykonane były z krokiem pomiarowym $20 \mathrm{~cm}$, przy założonym czasie akwizycji $10 \mathrm{~min}$. Rdzenie miały średnicę $6,4 \mathrm{~cm}$, a ich stan był dobry, z nielicznymi ubytkami.

Wstępne badania na rdzeniach o niskiej aktywności, wykonane nową aparaturą pozwoliły uzyskać wyniki rzeczywistej zawartości pierwiastków promieniotwórczych. W porównaniu ze standardowymi pomiarami rdzenia (GL), 


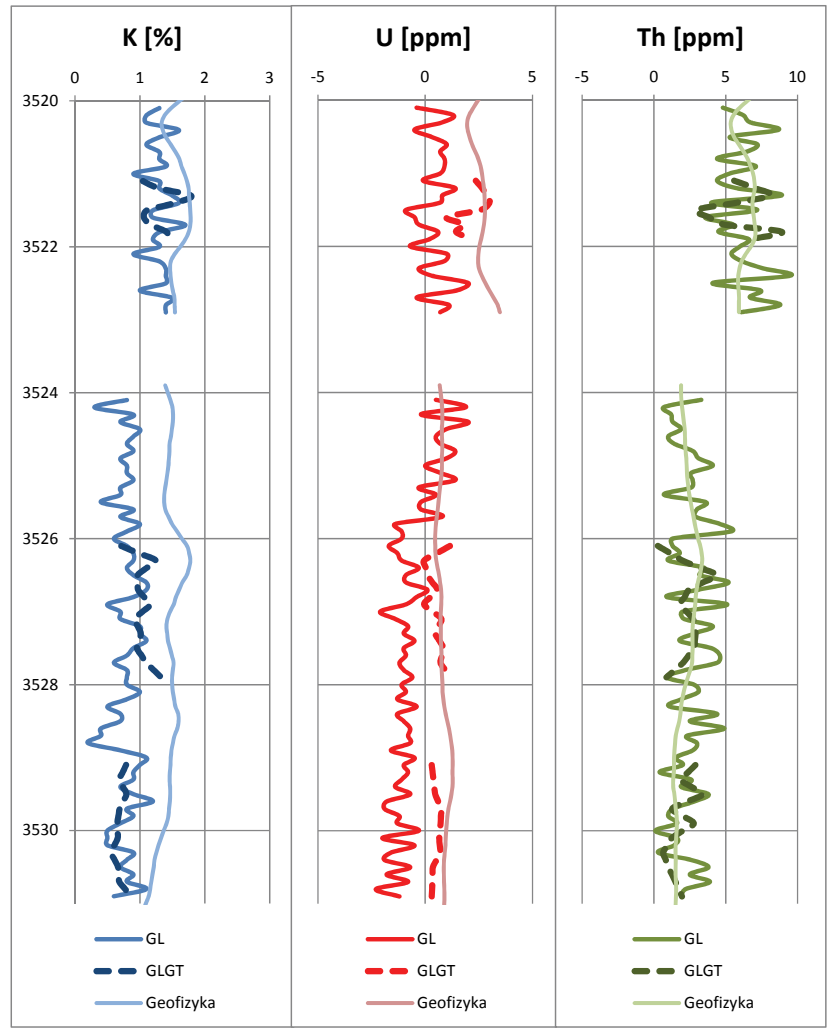

Rys. 4. Wyniki spektrometrycznych pomiarów gamma. GL, GLGT - pomiary rdzeni; Geofizyka - pomiary geofizyki otworowej (Skupio et al., 2018)

Fig. 4. Spectrometric gamma measurement results. GL, GLGT core measurements; Geofizyka - well logs (Skupio et al., 2018)

zmiana układu pomiarowego pozwoliła na otrzymanie informacji ze stref o niskiej zawartości uranu, zbliżone do pomiarów geofizycznych. W przypadku potasu (K\%) zauważalne jest zaniżenie wyników na rdzeniu obiema metodami w stosunku do pomiarów geofizycznych. Przyczyną tego zjawiska może być wpływ płuczki potasowej, która zawyżyła wyniki pomiarów otworowych.

Po uzyskaniu pozytywnych wyników dla rdzenia testowego, do dalszych badań wykorzystano rdzeń wiertniczy z otworu J-1, również reprezentujący utwory czerwonego spągowca. Pomiary wykonano spektrometrem GL oraz spektrometrem GLGT na 10-metrowym odcinku rdzenia. Dodatkowo w tym przypadku przeprowadzono serię badań laboratoryjnych. Badania urządzeniem GL wykonano z krokiem pomiarowym $10 \mathrm{~cm}$, po czym wyniki z uszkodzonych partii rdzenia lub ich braku zostały usunięte. Badania z wykorzystaniem aparatury GLGT wykonywano ze zmiennym krokiem, a punkty pomiarowe wyznaczono dla dobrze zachowanych partii rdzenia. Czas pomiarowy w przypadku obu metod ustawiono na 5 min. Aparatura GLGT rejestruje dwa widma jednocześnie, co właściwie pozwala uzyskać wynik pomiaru 10 minutowego. Wyniki pomiarów zestawiono na tle krzywych geofizyki otworowej w postaci profilowań (rys. 5).

Wyniki spektrometrycznych pomiarów gamma przeprowadzonych na rdzeniu wiertniczym z otworu J-1, ukazują różnicę w czułości oraz dokładności aparatury. Koncentracja potasu w przypadku pomiarów geofizycznych jest zawyżona w stosunku do pomiarów rdzeni, na co mogła mieć wpływ płuczka potasowa. Wykonane badania laboratoryjne potwierdziły zawyżający wpływ czynników występujących w otworze. Zmierzone wartości uranu oraz toru są na niskim poziomie i są bardzo zbliżone do wyników z sondy otworowej. Spektrometr GL w wielu punkach nie pozwolił zarejestrować wartości dla uranu oraz toru powyżej tha pomiarowego. Pomiary wykonane w spektrometrze GLGT umożliwiły osiągnięcie pełnych wyników w badanym interwale rdzenia dzięki lepszemu odcięciu tła. Na jakość krzywych spektrometrycznych wpływają fluktuacje statystyczne, które są znacznie większe w przypadku profilowania GL. Krzywe wynikowe uzyskane z pomiarów GLGT mają mniejszy rozrzut, co dokładnie można zauważyć w przypadku pomiarów toru. Pomiar geofizyczny 10 centymetrowej warstwy na głębokości 2231 metra o wysokiej zawartości uranu jest obarczony dużym błędem, wynikającym z niskiej miąższości. Sonda zarejestrowała wydzieloną warstwę, natomiast znacznie zaniżyła jej wynik i wykazała większą jej miąższość. Pomiary rdzeni wykazały mniejsza miąższość warstwy, na co miała wpływ większa rozdzielczość metody. Wynik również jest nieznacznie zaniżony z powodu niekompletnego rdzenia $\mathrm{w}$ danym odcinku. Po przeprowadzeniu badań na całym rdzeniu pobrano próbki do analiz laboratoryjnych z wykorzystaniem aparatury MAZAR.

Wyniki kompletu badań zestawiono w postaci profilowań na czterech osobnych wykresach - dla potasu, uranu, toru oraz całkowitej zawartości pierwiastków promieniotwórczych (GR), przedstawionej w jednostkach API. Wartości GR w jednostkach API obliczone zostały według ogólnego wzoru: $\mathrm{API}=4 \mathrm{Th}+8 \mathrm{U}+16 \mathrm{~K}$ (Ellis, 2008).

\section{Wnioski}

Pomiary rdzeni skał o niskiej aktywności (piaskowce czerwonego spągowca) są możliwe w przypadku zapewnienia odpowiedniej obudowy aparatury badawczej oraz detektorów o wysokiej wydajności. W pracy przedstawiono nowy spektrometr gamma (GLGT) i porównano go wraz z urządzeniem Gamma Logger (GL). Otrzymane wyniki wykazały znaczną poprawę rejestrowanego sygnału i umożliwiły uzyskanie pełnych informacji na temat koncentracji naturalnych pierwiastków promieniotwórczych w skałach czerwonego spągowca, szczególnie dla uranu i toru. Oceniono również rozdzielczość pomiaru, która jest identyczna dla GL i GLGT. Przeprowadzone porównania pozwalają stwierdzić, że w zależności od jakości rdzeni oraz ich aktywności należy odpowiednio dopasować metodę pomiarową. Aparatura GLGT pozwoli na wprowadzenie nowej metodyki badawczej przeznaczonej do pomiarów rdzeni wiertniczych o niskiej zawartości pierwiastków promieniotwórczych. 


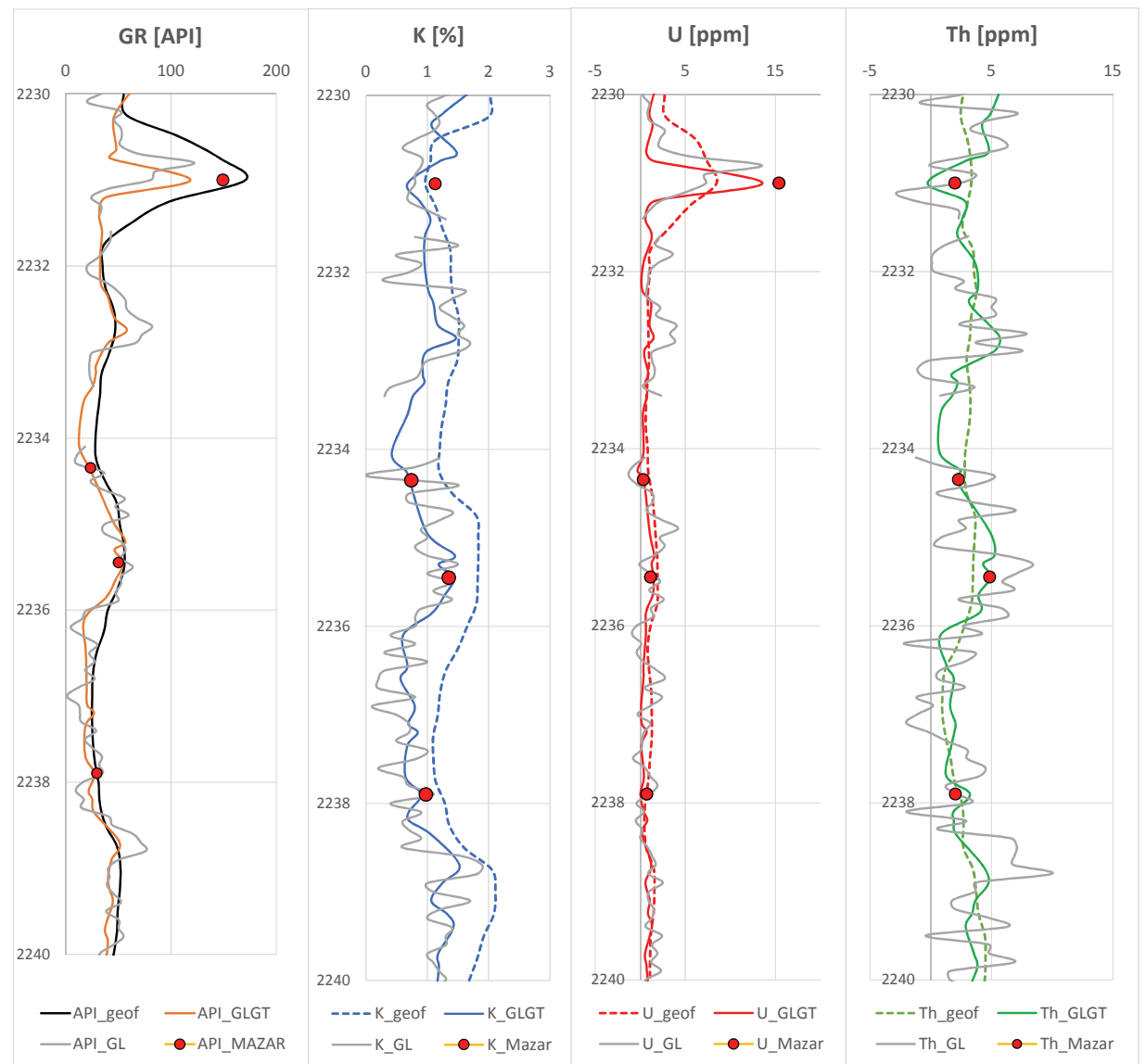

Rys. 5. Wyniki badań radiometrycznych dla otworu J-1, na tle pomiarów geofizyki otworowej

Fig. 5. Radiometric measurement results for J-1 borehole with well logs dataset
Gamma Ray Calibration Facility. Applied Radiation and Isotopes, 122: 47-56.

Korun M., Vodenik B., Zorko B., 2014. Determination of the shielding factors for gamma-ray spectrometers. Applied Radiation and Isotopes, 87: 372-375.

Lindstorm R.M., 2017. A second-generation low-background gamma-ray spectrometer. Applied Radiation and Isotopes, 126: 191-193. Melintescu A., Chambers S.D., Crawford J., Williams A.G., Zorila B., Galeriu D., 2018. Radon-222 related influence on ambient gamma dose. Journal of Environmental Radioactivity, 189: 67-78.

Procedura pomiaru rozkładu naturalnej promieniotwórczości rdzeni wiertniczych przy wykorzystaniu spektrometru gamma. PBN-14/ SW-1. 2012.

Procedura pomiaru zawartości pierwiastków promieniotwórczych: radu, toru i potasu metodą spektrometrii gamma w skałach, płynach złożowych i płuczkach wiertniczych przy zastosowaniu analizatora typu MAZAR. PB-04/ SW-1, 2018.

Rider M., 1996. The Geological Interpretation of Well Logs. Second Edition, Whittles Publishing.

Skupio R., 2015. Accuracy assessment of the determination of radioactive elements concentration on shale cores. Nafta-Gaz, 6: 390-399. Skupio R. Dohnalik M., 2015. Improvement spectrometric gamma measurements on shale cores with the use of the BGO scintillation detector. Nafta-Gaz, 11, 847-855. DOI: 10.18668/NG2015.11.06

Skupio R., Kubik B., Wolański K., 2018. Spektrometryczne profilowanie gamma dla rdzeni wiertniczych o niskiej aktywności. Międzynarodowa Konferencja Naukowo-Techniczna Geopetrol 2018. Materiały konferencyjne: 359-364.

Strona internetowa: www.crystals.saint-gobain.com (dostęp: 10.2015).

Van der Graaf E.R., Rigollet C. Maleka P.P., Jones D.G., 2007. Testing and assessment of large BGO detector for beach monitoring of radioactive particles. Nuclear Instruments and Methods in Physics Research A, 575: 507-518.

Yuan C., Zhou C., Zhang F., Hu Song, Li C., 2015. A novel method for quantitative geosteering using azimuthal gamma-ray log. Applied Radiation and Isotopes, 96: 63-70.

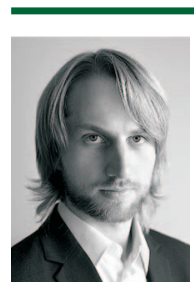

Mgr inż. Rafał SKUPIO

Asystent w Zakładzie Geofizyki Wiertniczej Instytut Nafty i Gazu - Państwowy Instytut Badawczy ul. Lubicz 25 A

31-503 Kraków

E-mail: rafal.skupio@inig.pl

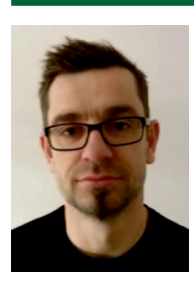

Mgr inż. Krzysztof WOLAŃSKI

Starszy specjalista petrofizyk

PGNiG SA w Warszawie

Oddział Geologii i Eksploatacji

Dział Projektowy w Pile

ul. Boh. Westerplatte 15, 65-034 Zielona Góra

E-mail: krzysztof.wolanski@pgnig.pl

Galford J.E., 2017. A Monte Carlo modeling alternative for the API 